Pécsi Tudományegyetem, Általános Orvostudományi Kar, II. Belgyógyászati Klinika és Nephrológiai-Diabetológiai Centrum, Pécs, ${ }^{1}$ RxTarget Kft., Szolnok, ${ }^{2}$ Állatorvostudományi Egyetem, Budapest, ${ }^{3}$ Bajcsy-Zsilinszky Kórház, Budapest, ${ }^{4}$ Semmelweis Egyetem, Általános Orvostudományi Kar, I. Belgyógyászati Klinika, Budapest, ${ }^{5}$ Miskolci Egyetem, Egészségügyi Kar, Elméleti Egészségtudományok Intézet, Miskolc, ${ }^{6}$ Pavol Jozef Šafárik University, Faculty of Medicine, Department of Paediatrics and Adolescent Medicine, Kassa, Szlovákia ${ }^{7}$

\title{
A fiatal felnőtt, 1-es típusú cukorbetegségben szenvedők halálozási kockázata magasabb, mint hasonló korú, 2-es típusú diabeteses társaiké: átfogó, reprezentatív hazai felmérés eredményei
}

\author{
Kiss Zoltán dr., ${ }^{(1)}$ Rokszin György dr., ${ }^{(2)}$ Abonyi-Tóth Zsolt dr., ${ }^{(2,3)}$ Jermendy György dr., ${ }^{(4)}$ \\ Kempler Péter dr., ${ }^{(5)}$ Barkai László dr., ${ }^{(6,7)}$ Wittmann István dr. ${ }^{(1)}$
}

Kiss Zoltán és Rokszin György egyenlő mértékben járult hozzá a munka létrejöttéhez.

Magyar nyelvű másodközlés a kiadó engedélyével. Első megjelenés helye: Kiss Z, Rokszin G, Abonyi-Tóth Z, et al.: Young adult patients with type 1 diabetes have a higher risk of mortality than those of similar age with type 2 diabetes: A nationwide analysis in Hungary. Diabetes Metab Res Rev 2019; 35: e3190. D0l: 10.1002/dmrr.3190

\begin{abstract}
Összefoglalás
Háttér: Kevés közlemény hasonlitja össze az 1-es tipusú cukorbetegség szövödményeit a hasonlóan fiatal korú, 2-es típusú cukorbetegségben szenvedökével. Vizsgálatunk célja a két cukorbetegség-tipusban megfigyelhetö mortalitási és morbiditási kockázat összehasonlitása volt 40 év alatti életkorúaknál. Módszerek: Azonositottunk minden a Nemzeti Egészségbiztositási Alapkezeló adatbázisában 2001 és 2014 között szereplö, fiatal felnött, 1-es tipusú cukorbetegségben szenvedö beteget ( $n=11863$ ) és adataikat összehasonlitottuk egy hasonló korú, fiatal felnött 2-es típusú diabeteses betegcsoportéval ( $n=47931)$. Az összes halálozás, myocardialis infarctus, stroke, bármilyen daganatos megbetegedés, diabeteses ketoacidosis és a hypoglykaemia elöfordulását a cukorbetegség diagnózisától a halál bekövetkeztéig, vagy a tanulmányi idöszak lezártáig követtük. Eredmények: Az összes halálozás kockázata magasabb volt 1-es, mint 2-es típusú cukorbetegségben (esélyhányados; $95 \%$-os Cl: 2,17; 1,95-2,41; $p<0,0001)$. A myocardialis infarctus $(0,90 ; 0,71-1,13 ; p=0,360)$ és a stroke $(1,06$; $0,87-1,29 ; p=0,582)$ kockázata nem különbözött a két diabetesformában. Ezzel szemben a daganatos megbetegedések
\end{abstract}

Közlésre érkezett: 2020. október 23. • Közlésre elfogadva: 2020. november 30.

A levelezésért felelös szerzö: Prof. Dr. Wittmann István

Pécsi Tudományegyetem, Általános Orvostudományi Kar, II. Belgyógyászati Klinika és Nephrológiai-Diabetológiai Centrum

7624 Pécs, Pacsirta u. 1.

E-mail: istvan.wittmann@aok.pte.hu 
$(1,35 ; 1,15-1,59 ; p=0,0003)$, a dializis $(2,20 ; 1,76-2,75 ; p<0,0001)$, a hypoglykaemia $(7,70 ; 6,45-9,18 ; p<0,0001)$ és a ketoacidosis $(22,12 ; 19,60-25,00 ; p<0,0001)$ kockázata magasabb volt 1-es, mint 2-es típusú cukorbetegségben. Következtetések: Az 1-es típusú cukorbetegségben gyakrabban elöforduló diabeteses ketoacidosis és hypoglykaemia, valamint a magasabb tumorés dializiskockázat játszhat szerepet ezen betegcsoport magasabb halálozásában.

Kulcsszavak: összes halálozás, tumor, diabeteses ketoacidosis, dialíziskezelés, hypoglykaemia, 1-es típusú cukorbetegség, 2-es típusú cukorbetegség

Rövidítések

ATC: Anatomical Therapeutic Chemical; DKA: diabeteses ketoacidosis

A cukorbetegség két leggyakoribb formája az 1-es (T1DM) és a 2-es típusú (T2DM). Mindkettő hatást gyakorol a diabeteses szövődmények kialakulására, ugyanakkor a hatásuk mértéke különbözhet a kardiovaszkuláris és renalis szövődmények, valamint a tumorok, a hypoglykaemia és a diabeteses ketoacidosis (DKA) tekintetében.

\section{1-es típusú cukorbetegség (T1DM)}

Számos megfigyeléses vizsgálat mutatott jelentősen emelkedett halálozást és diabeteshez köthető komorbiditást T1DM-ben szenvedőkben. ${ }^{1}$ A svéd regiszterből gyűjtött adatok alapján a T1DM-ben szenvedők összes halálozásának kontrollcsoporthoz viszonyított relatív kockázata 3,52. ${ }^{2}$ A cukorbetegek gondozásában megfigyelhető, jelentős javulás ellenére egy dán analízis szintén magasabb mortalitási rátát mutatott a legalacsonyabb életkorban kezdődő és a férfi T1DM-esekben. ${ }^{3}$

Lung és mtsai T1DM-ben szenvedők összes halálozási kockázatát vizsgáló metaanalízisében 3,82es relatív kockázatot találtak az átlagpopulációhoz képest. Mindazonáltal jelentős javulásról számoltak be, tekintve, hogy a halálozás relatív kockázata az 1971-ben mért 5,8-ról 1990 utánra 3,11-re csökkent. ${ }^{4}$ Egy, a Svéd Nemzeti Regiszterből készült másik analízis a mortalitás és a kardiovaszkuláris megbetegedések kockázatának 40\%-os csökkenését mutatta T1DM-ben szenvedőkben. ${ }^{5}$ Finnországban is javult a T1DM-esek túlélése, ugyanakkor ebben a tanulmányban a DKA-hoz köthető halálozás magasabb kockázatát találták a finnországihoz képest Észtországban és Litvániában. ${ }^{6}$

\section{2-es típusú cukorbetegség (T2DM)}

Bár a T2DM előfordulása idősebb életkorban magasabb, ugyanakkor emelkedő incidenciát és prevalenciát látunk a fiatalabbak körében, ami a hosszú távú kardiovaszkuláris morbiditás növekedését vonja maga után, a hypoglykaemiának való hosszabb kitettség következményeként. ${ }^{7}$ Egy kanadai klinikai adatbázis alapján végzett tanulmányban a diagnózis és a veseszövődmények megjelenési idejének korábbra tolódását írták le T2DM-ben szenvedőkben, ám nem találtak különbséget a retinopathia kapcsán. Ebben a vizsgálatban ritkák voltak a makrovaszkuláris szövődmények, ugyanakkor mikrovaszkuláris események, mint például a dialíziskezelés szükségessége már a cukorbetegség diagnózisát követő 10 éven belül megjelentek. ${ }^{8}$

Egy ausztrál csoportban a hosszú távú morbiditási és mortalitási rizikó magasabb volt korai kezdetű (15-31 év) T2DM-ben, mint a fellépés szokásos életkora (40-50 év) esetén (HR 3,4). ${ }^{9}$

\section{Az 1-es és a 2-es típusú cukorbetegség összehasonlítása}

Számos vizsgálat foglalkozott a T1DM-ben és a T2DM-ben tapasztalt morbiditás és mortalitás öszszehasonlításával fiatal életkori kohorszokban. ${ }^{10,11}$ Alacsonyabb összes halálozási és kardiovaszkuláris morbiditási kockázat volt jellemző T1DMben, mint T2DM-ben. ${ }^{5,10}$ A fiatal T2DM-esekben megfigyelt, súlyosabb komorbiditások ellenére a hosszú távú túlélés hasonló volt a két diabetestípusban. ${ }^{12}$ Constantino többletmortalitásról számolt 
be T2DM-ben szenvedőkben, mint T1DM-ben ( $11 \%$ vs. $6,8 \%, p=0,03)$, és magasabb összes halálozást talált (HR 2,0; $p=0,003)$. A kardiovaszkuláris mortalitás szintén gyakoribb volt T2DM-ben (HR 3,5; p=0,004). ${ }^{13}$ Hasonlóan, egy nagy, prospektív, kohorszalapú, svéd vizsgálatban háromszoros mortalitási rátát találtak 15-34 éves életkorú T2DM-esekben. ${ }^{14}$

Dart magasabb 10 éves túlélési rátát talált 1-18 év közötti T1DM-ben szenvedőkben, mint T2DMben $(99,5 \%$ and $91,4 \%)$, amely 20 év után tovább csökkent 97,6 és $77,5 \%$-ra. ${ }^{15}$ Dart a végstádiumú veseelégtelenség kialakulásának emelkedett kockázatáról is beszámol fiatal T2DM-es betegekben, összehasonlítva 1-18 év közötti T1DM-esekkel. ${ }^{15}$ Ezt a megfigyelést a két diabetesforma között megerősítették kínai és japán tanulmányok is. ${ }^{16,17}$

A DKA prevalenciája magas volt fiatal T1DMben szenvedőkben, s 2002 és 2010 között állandó szinten mozgott (2002-2003: 30,2\%; 2004-2005: 29,1\% és 2008-2010: 31,1\%; p=0,42), míg fiatal, T2DM-ben szenvedőkben ritkább és csökkenő tendenciájú volt (2002-2003: 11,7\%; 2008-2010: 5,7\%; $\mathrm{p}=0,005) .{ }^{18}$ Egy másik, három regisztert és öt országot felölelő közlemény szintén magas $(5,0-7,1 \%)$ DKA-rátáról számol be fiatal T1DM-esekben. ${ }^{19}$ Barski mindkét diabetestípusban meghatározta a DKA halálozási kockázatát. Súlyosabbnak, roszszabb kimenetelünek találta azt a T2DM-ben szenvedőkben, mint T1DM-ben. ${ }^{20}$

Jól ismert tény, hogy a T2DM-es betegek tumorrizikója emelkedett a nem cukorbeteg populációhoz képest. ${ }^{21}$ Másrészről viszont meglehetősen kevés adat áll rendelkezésre az 1-es típusúak tumor-asszociált morbiditásáról és mortalitásáról. ${ }^{22,23}$

Nemzeti vizsgálatunk célja a fiatal T1DM-ben és T2DM-ben szenvedők mortalitási és morbiditási kockázatainak összehasonlítása volt, felhasználva a Nemzeti Egészségbiztosítási Alapkezelő (NEAK) adatait.

\section{Módszerek}

\section{A vizsgálat felépítése}

Retrospektív kohorszvizsgálatunkba a NEAK adatbázisából vontunk be olyan, legfeljebb 40 éves betegeket, akiknél 2001. január 1. és 2014. október
31. között antidiabetikus kezelés (Anatomical Therapeutic Chemical [ATC] A10) indult. Tanulmányunkban anonim, összesített betegadatokkal dolgoztunk. A fenti időszak összes magyarországi T1DM-es betegét bevontuk. Két hasonlóan fiatal felnőtt, de nem illesztett csoportot hasonlítottunk össze, amelyekben a T1DM-ben, illetve T2DMben szenvedők aránya több, mint 1:4 volt.

A diabetest, illetve a társbetegségeket a Betegségek Nemzetközi Osztályozása (BNO) 10. verziója alapján definiáltuk. Az adatforrás információval szolgált a bármilyen okú halálozásról, a myocardialis infarctus (BNO-10 I21-24), az ischaemiás és a hemorrágiás stroke (BNO-10 I61-63, G4630, G4640,), a dialíziskezelés, a tumorok (BNO-10 C és D csoport), a DKA (BNO-10 E1010, E1110 és E1410), valamint a hypoglykaemia (BNO-10 E1600, E1610 és E1620) incidenciájáról. Tekintettel a dialízis meglehetősen költséges voltára, azt a NEAK külön, e célt szolgáló adatbázisában vezetik kezelésenként, TAJ-szám megadásával, nélkülözve a BNO kódok használatát. Így ezen beavatkozásokról ebből a külön adatbázisból nyertünk információt.

A T1DM-et a következők szerint definiáltuk: (a) a rögzítés idején E10 BNO kódot használtak, (b) a beteg a diagnózis időpontjában 40 év alatti volt és (c) az első 6 hónapban nem került sor orális antidiabetikum felírására. Az antidiabetikus kezelésben (ATC A10) részesülő, de a fenti feltételeknek meg nem felelő betegeket vettük T2DMesnek. A T1DM és a T2DM részletes definíciója egy korábbi közleményben szerepel. ${ }^{24}$ A policisztás ovárium szindrómás (BNO 10 E282) betegeket kizártuk az analízisből.

A diabetes fellépésének idejét az arra vonatkozó BNO kód első megjelenésének, vagy az inzulin/nem inzulin kezelés első felírásának idejében határoztuk meg. Korábbi stroke-ra, illetve myocardialis infarctusra vonatkozó adatokat is kerestünk. Kizárólag kórházi bennfekvés során rögzített, a diabetes diagnózisát követően bekövetkezett eseményeket (myocardialis infarctus, stroke, dialízis, tumor, DKA és hypoglykaemia) vettük számításba. A halálesetek dátumát is a NEAK adatbázisából nyertük. Mivel adott halálesetek okát nem tudtuk differenciálni a rendelkezésre álló adatok alapján, így tanulmányunkban az összes halálozással számoltunk. 


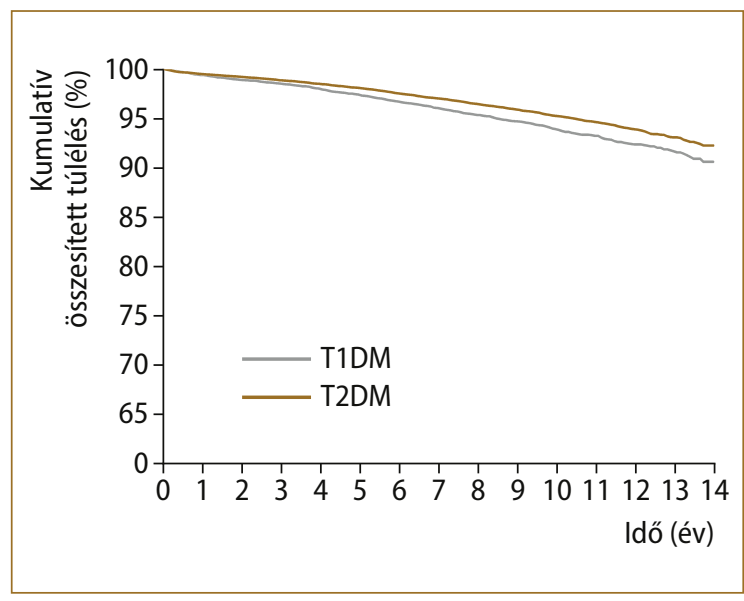

1. ábra. Össztúlélés Kaplan-Meier szerint ábrázolva, T1DM-ben és T2DM-ben szenvedők esetén
Az összes halálozás és a különböző morbiditások előfordulását hasonlítottuk össze T1DM, illetőleg T2DM esetén.

A tanulmány a Pécsi Tudományegyetem Általános Orvostudományi Kara Regionális $\mathrm{Ku}$ tatásetikai Bizottságának jóváhagyásával zajlott (engedélyszám: 6962/2017), céges szponzoráció nélkül. A vizsgálati protokollt a NEAK is áttekintette, befogadta (azonosító szám: S04/161/2016).

\section{Statisztikai analízis}

Túlélési analízisként Cox-regressziót használtunk, ahol a cukorbetegség típusa szerepelt elkülönítő változóként. A modellt korrigáltuk a kiindulási nemi és életkori különbségekre. Az eredmények megjelenítésére Kaplan-Meier-görbéket használtunk.

1. táblázat. Az 1-es és 2-es típusú cukorbetegségben szenvedő betegek kiindulási adatai.

\begin{tabular}{|c|c|c|c|}
\hline & T1DM & T2DM & P \\
\hline Nő (\%) & 11863 & 47931 & $<0,0001$ \\
\hline Átlagéletkor a diagnózis idején (95\%-os Cl) (év) & $21,63(21,42-21,85)$ & $33,47(33,41-33,53)$ & $<0,0001$ \\
\hline Átlagos követési idő a diagnózistól (95\%-0s Cl) (év) & $6,52(6,45-6,59)$ & $6,56(6,62-6,69)$ & 0,0008 \\
\hline Megelőző myocardialis infarctus (\%) & 0 & $72(0,2)$ & $<0,0001$ \\
\hline Megelőző stroke (\%) & 0 & $74(0,2)$ & $<0,0001$ \\
\hline
\end{tabular}

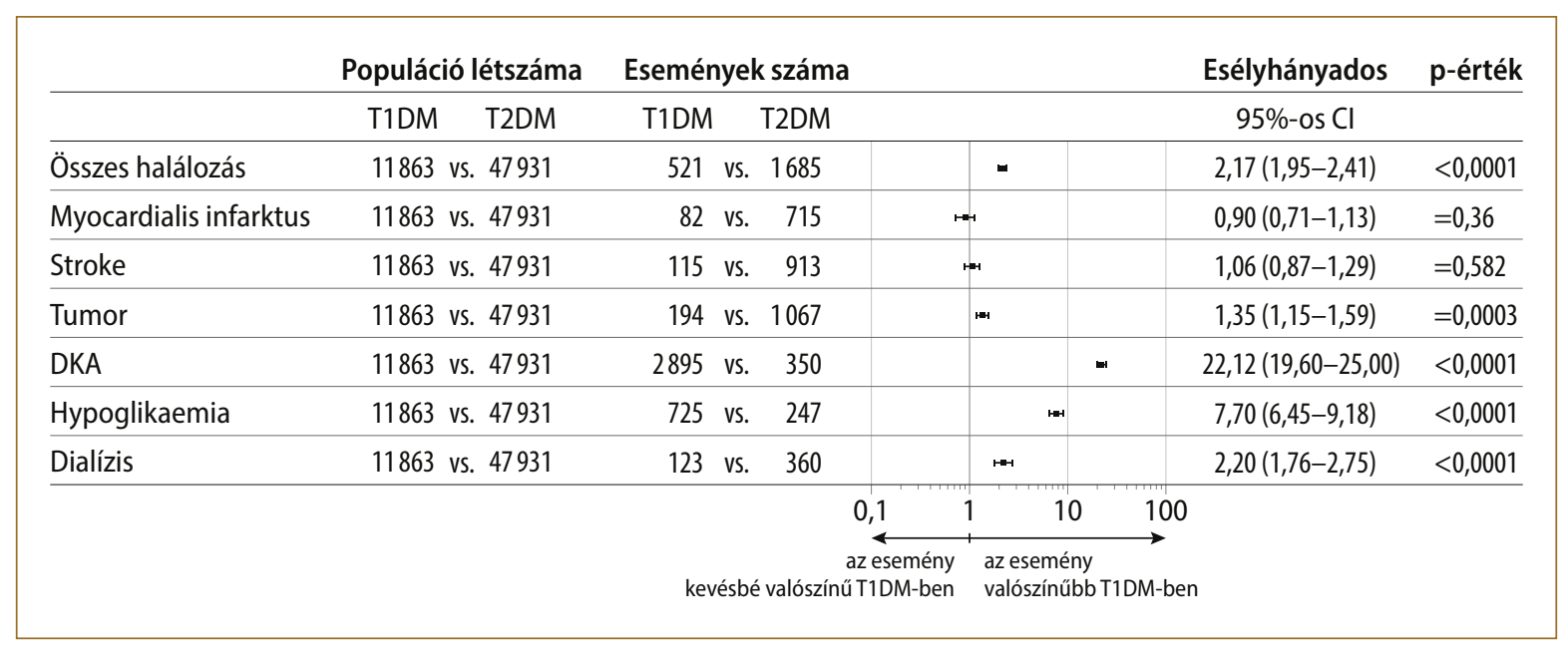

\section{2. ábra. Az események és a mortalitás, illetve morbiditás esélyhányadosai}


Adatainkat nemekre stratifikáltuk és eredményeinket korrigáltuk a két csoport között megfigyelhető, nemi aránybeli különbségre. Az életkor és a követési idő átlagát Welch-féle kétmintás teszttel hasonlítottuk össze. A követési időszakot a diabetes fellépésétől számítottuk. A myocardialis infarctus, illetve stroke bekövetkeztét megelőző periódusok arányát khí-négyzet próba segítségével vetettük össze. Számításaink során az R Software 3.4.2 verziójának (2017-09-28) survival, survminer és multcomp csomagját alkalmaztuk. ${ }^{25}$

\section{Eredmények}

Betegcsoportjaink kiindulási adatait az 1. táblázat mutatja. A T1DM-ben szenvedő betegek 35,4\%-a volt nő, átlagéletkoruk 21,63 év (95\%os CI 21,42-21,85) volt, kardiovaszkuláris eseményük korábban nem történt. A tanulmányba 47931 hasonló korú, fiatal felnőtt, T2DM-ben szenvedő, nem illesztett beteget is bevontunk. A vizsgált 2001 és 2014 közötti időszakban a T1DM-es betegek összes halálozása magasabb volt a T2DM-es társaikénál (1. ábra), korrigálást követően ez 2,17-es relatív kockázatot mutatott $(1,95-2,41 ; \mathrm{p}<0,0001)$ (2. ábra). A 10 éves túlélés $93,84 \%$ volt T1DM-ben és $95,23 \%$ T2DM-ben, amely a 167 hónapos követési idő végére $1,65 \%$-os $(90,61 \%$ vs. 92,26\%) különbséget eredményezett.

Ezzel ellentétben a myocardialis infarctus, a stroke és a tumoros megbetegedések kockázata magasabb volt T2DM-ben szenvedők esetén (3., 4., 5. ábra): a 10 éves, eseménymentes túlélés (T1DM vs. T2DM) $99,08 \%$ vs. $98,00 \%$ volt $\mathrm{MI}$, $98,64 \%$ vs. $97,31 \%$ stroke és $97,90 \%$ vs. $97,07 \%$ tumorok tekintetében. Életkorra és nemre való korrigálást követően azonban nem találtunk szignifikáns különbséget a két diabetestípus között myocardialis infarctus $(0,90 ; 0,71-1,13 ; \mathrm{p}=0,3600)$ és stroke $(1,06 ; 0,86-1,29 ; \mathrm{p}=0,5820)$ esetén, a tumorkockázat viszont magasabbnak bizonyult T1DM-ben $(1,35 ; 1,15-1,59 ; \mathrm{p}=0,0003)$. A halálozással párhuzamosan a DKA, a hypoglykaemia és a dialízis kockázata magasabb volt T1DM-ben (6., 7., 8. ábra). A 10 éves, eseménymentes túlélés (T1DM vs. T2DM) $71,99 \%$ vs. $99,08 \%$ volt DKA, $91,89 \%$ vs. $99,33 \%$ hypoglykaemia és $98,62 \%$ vs. 99,02\% dialízis tekintetében; a korrigált relatív

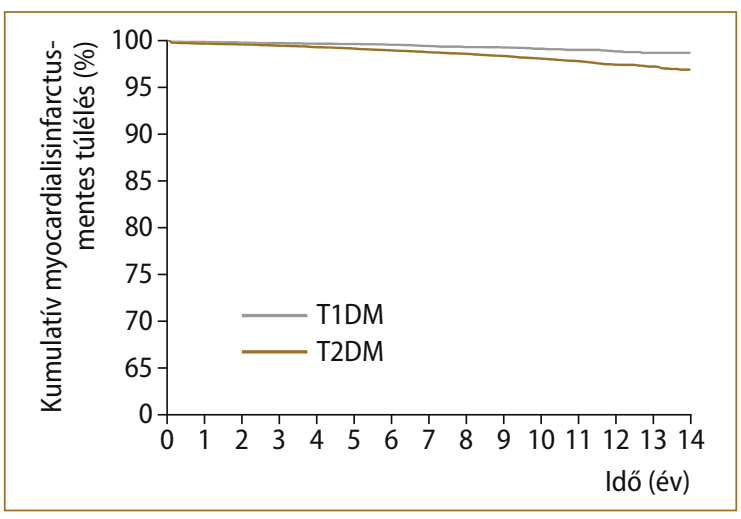

3. ábra. Myocardialisinfarctus-mentes túlélés T1DMben és T2DM-ben Kaplan-Meier szerint ábrázolva

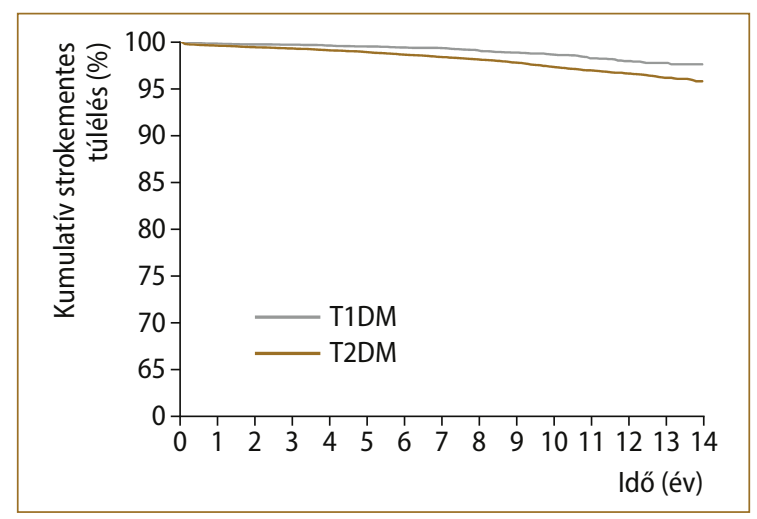

4. ábra. Stroke-mentes túlélés T1DM-ben és T2DM-ben Kaplan-Meier szerint ábrázolva

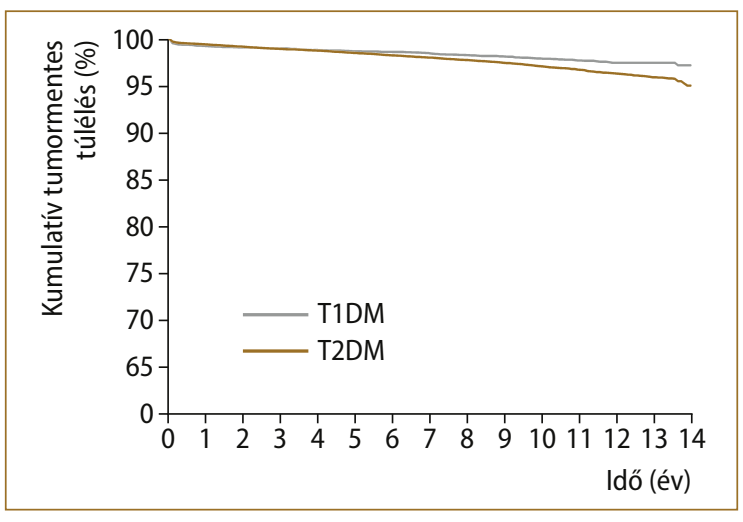

5. ábra. Tumormentes túlélés T1DM-ben és T2DM-ben Kaplan-Meier szerint ábrázolva 


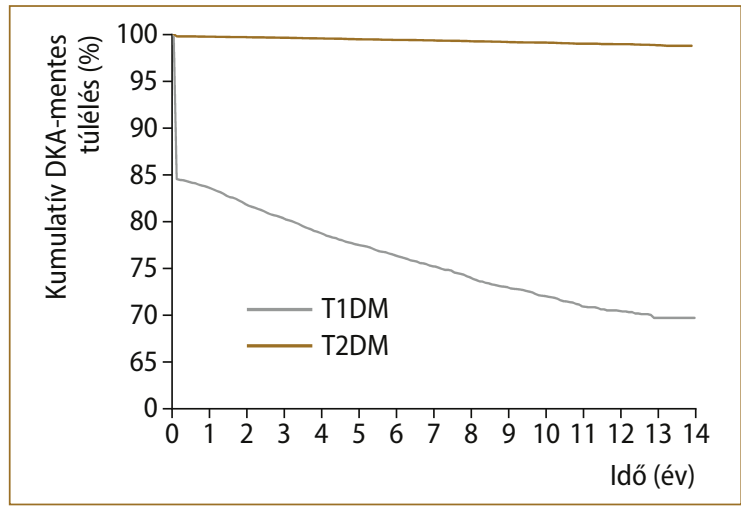

6. ábra. Diabetesesketoacidosis-mentes túlélés T1DMben és T2DM-ben Kaplan-Meier szerint ábrázolva

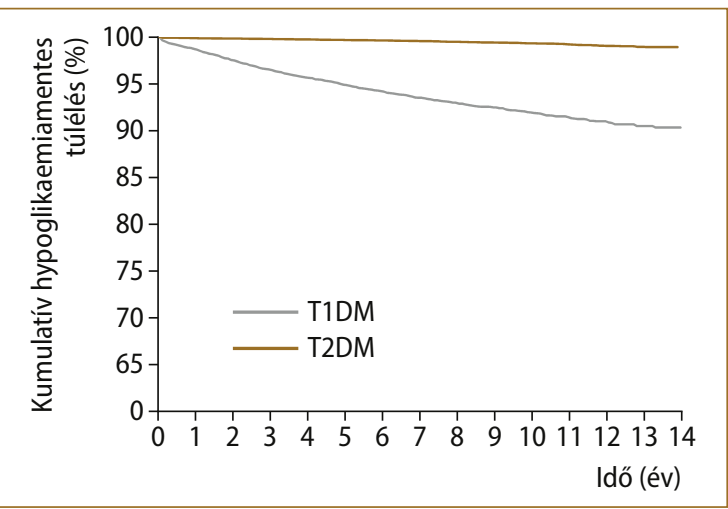

7. ábra. Hypoglykaemiamentes túlélés T1DM-ben és T2DM-ben Kaplan-Meier szerint ábrázolva

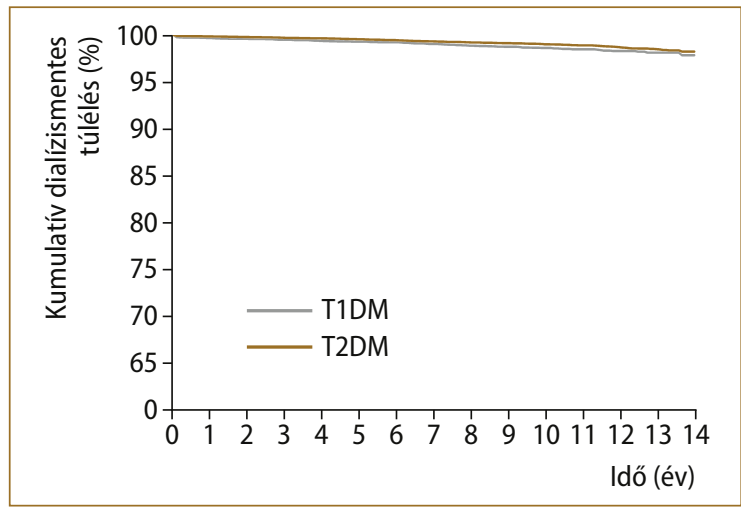

8. ábra. Dialízismentes túlélés T1DM-ben és T2DM-ben Kaplan-Meier szerint ábrázolva kockázat 22,12-nek, 7,70-nek és 2,20-nak bizonyult (2. ábra).

\section{Megbeszélés}

Hosszú távú, retrospektív, nemzeti vizsgálatunkban fiatal felnőtt (40 év alatti), T1DM-ben és T2DMben szenvedő betegek mortalitási és morbiditási kockázatbeli különbségeit hasonlítottuk össze.

Tanulmányunk fő eredményei a következők:

- a T1DM-ben szenvedők halálozási kockázata magasabb T2DM-es társaikénál;

- a kardiovaszkuláris események kockázatában nem találtunk különbséget, ellenben a tumorok, a DKA, a hypoglykaemia és a dialízis kockázata magasabb T1DM-ben.

Egy T1DM-es és T2DM-es betegeket összehasonlító, másik vizsgálatban kedvezőbb és javuló halálozási kockázatot írtak le T1DM-ben, ${ }^{11}$ ami ellentétes a mi eredményeinkkel. Constantino közleményében a T1DM-hez képest emelkedett relatív halálozási kockázatról számol be fiatal T2DM-es betegekben (HR [95\%-os CI], 2,0 [1,2-3,2]), ${ }^{13}$ ezt az eredményt megerősítette egy svéd tanulmány, ${ }^{14}$ valamint Dart és mtsai vizsgálata is. ${ }^{15}$ Ezekkel szemben, a mi tanulmányunkban magasabb összes halálozási kockázatot találtunk T1DM-ben szenvedőkben, mint T2DM-ben. E különbségek a populációk eltéréseire vezethetők vissza.

A T1DM-esek csoportjában, a (12 évvel) fiatalabb átlagéletkor ellenére meglepően magas halálozási kockázatot találtunk. Ez a váratlan eredmény a következőkkel magyarázható: jóllehet a kardiovaszkuláris kimenetelek tekintetében nem találtunk különbséget a két diabeteses csoport között, ugyanakkor a diabeteses halálozás további fő okai, a ketoacidosis, a hypoglykaemia, a vesekárosodás és a tumor szintén eredményezhetik a T1DM-esek csoportjának magasabb mortalitását. Mortalitási arányaink hasonlóak az észtországiakhoz és a litvániaiakhoz, amelyek szintén magasabb halálozást mutatnak T1DMben szenvedőkben. ${ }^{6}$ A 10 éves túlélés $94,3 \%$ volt Észtországban és 94,0\% Litvániában, szemben a Finnországban leírt 99,1\%-kal, ${ }^{6}$ míg a mi tanulmányunkban a hasonló hosszúságú követési idő alatt 93,84\%-nak mutatkozott. Észtországban és Litvániában a halálozás leggyakoribb okaként 
szereplő DKA magasabb rátáját igazolták Finnországhoz képest. $^{6}$

Vizsgálatunkban a DKA incidenciája 15,46\% volt a T1DM diagnózisakor, ami magasabb egy máshol közölt értékhez képest, ${ }^{19}$ és a követés idején is magas maradt.

Scibilia közleményében is a DKA-t jelölte meg a korai halálozás egyik okaként T1DM-ben, a Children's Hospital of Pittsburgh 1950 és 1980 közötti adatai alapján. Ez a kórállapot volt a vezető oka a T1DM-ben szenvedők korai halálozásának, míg hypoglykaemiához nem kötődött egyetlen haláleset sem. ${ }^{26}$

Ezzel egybevágóan Edge közlése szerint a DKA 83\%-ban szerepelt a cukorbetegséghez köthető halálozás okaként, míg a hypoglykaemia mindössze 8\%-ban volt felelős ezért fiatal T1DM-esek populációjában. ${ }^{27}$ A DKA korfüggő előfordulását a DVP adatbázis analízise során is leírták. ${ }^{28}$ Karges és mtsai azt találták, hogy a DKA miatti kórházi felvételek átlagos aránya 4,81/100 betegév volt, magasabb számban a $9,0 \%$ feletti $\mathrm{HbA}_{1 \mathrm{c}}$-vel rendelkezők, a 15 és 20 év közötti életkorúak és a 2 és 4,9 év közötti diabetestartamúak körében.

A DKA magas incidenciáján túl a hypoglykaemia előfordulását is magasnak találtuk T1DM-ben (HR: 12,52). E két akut T1DM-es szövődmény váratlanul magas előfordulása magyarázhatja a T1DM-kohorsz magasabb halálozását és vezethet a T2DM-mel összehasonlítva magas mortalitási kockázathoz (17\%).

Karges egy másik, átfogó, populációalapú kohorsz-vizsgálatában, ${ }^{29}$ ahol inzulinnal kezelt T1DM-es betegeket $(n=9814)$ párosítottak inzulinpumpa-kezelésen lévőkkel ( $\mathrm{n}=9814)$, a DKA-epizódok (3,64 vs. 4,26/100 betegév) és a hypoglykaemiák (9,55 vs. 13,97/100 betegév) ritkábban fordultak elő inzulinpumpa-kezelés mellett. Ezek az eredmények bizonyították a pumpakezelés kedvezőbb klinikai kimenetellel való összefüggését, ami alapján várható a magyarországi T1DM-es betegek helyzetének javulása is.

Mindazonáltal egy, a közelmúltban Rawshani és mtsai által közölt, átfogó tanulmányban ${ }^{30}$ - amely svéd T1DM-es betegek korfüggő kardiovaszkuláris komorbiditását és mortalitását vizsgálta az 1998-2012 közötti időszakban - azt találták, hogy a diabetes diagnózisakor az életkor fontos prognosztikai faktora a túlélésnek és valamennyi kardiovaszkuláris eseménynek. Az összes halálozás tekintetében a HR 4,11 (3,24-5,22) volt a 0-10 éves kohorszban, míg mindössze 2,83 (2,38-3,37) a 26-30 éves csoportban. Hasonlóan emelkedett kockázat mutatkozott a fiatalabbaknál fellépő diabetes esetén, különböző kardiovaszkuláris eseményekre nézve: a HR koszorúér-betegségre 30,50 vs. 6,08 ; stroke-ra 6,45 vs. 3,20 volt. A többletkockázat magasabb volt nőkben, különösen a 0-10 éves kohorsz myocardialis infarctusra vonatkozó adatát nézve (HR 92,07), míg ez a kockázat férfiakban mindössze 15,11 volt. Ez az eredmény részben szintén magyarázza a T1DM-esek csoportjának vizsgálatunkban megfigyelt magasabb mortalitását, hiszen ez a populáció a T2DM-esek csoportjánál korábbi diabeteskezdetű volt.

A túlélés Kaplan-Meier-görbe szerinti ábrázolása alapján T2DM-ben magasabb tumorrizikót várnánk, ugyanakkor a korra történő korrigálást követően végzett Cox-analízis a T1DM-ben talált emelkedett kockázatot. Ez ugyancsak alátámasztja a T1DM-ben tapasztalt, magasabb mortalitási eredményeket, és felhívja a figyelmet a fiatal felnőttek tumorrizikója kapcsán végzendő, további vizsgálatok szükségességére.

Tanulmányunk több erősséggel és gyengeséggel is rendelkezik. A követési idő hossza, az 1-es és 2-es típusú cukorbetegségben szenvedők csoportjának létszáma, a számos diabeteshez köthető komorbiditás vizsgálata és az események magas száma megfelelő statisztikai erőt kölcsönzött analízisünknek.

Vizsgálatunk gyengeségei közé tartozik, hogy abba csak az antidiabetikumot használó cukorbetegeket válogattuk be, míg a pusztán életmódterápián lévő T2DM-eseket nem. Hangsúlyozzuk továbbá, hogy az átlagéletkor különbözött a két csoportban: T1DM-ben 21,63 $(21,42-21,85)$ év, T2DM-ben 33,47 (33,4-33,53) év volt. Ezentúl megjegyzendő, hogy a NEAK adatbázisa híján van bizonyos fontos befolyásoló tényezőknek, úgymint a $\mathrm{HbA}_{1 \mathrm{c}}$, koleszterinszint, BMI, vérnyomás, végül a testsúly, ami magyarázza a talált, de adatok hiányában fel nem deríthető hátterű különbségeket.

Mivel a NEAK adatbázisában nem szerepel specifikus halálok, így csak az összmortalitást tudtuk vizsgálni, ami számottevő hátrányt okozott, tekintve, hogy az első kardiovaszkuláris események jelentős hányada fatális kimenetelü. 
Eredményeink alapján kimondható, hogy a T2DM-ben nagyobb számban bekövetkező kardiovaszkuláris és daganatos megbetegedések ellenére, a DKA és a hypoglykaemia magasabb előfordulása vezethet vizsgálatunkban a T1DM-ben szenvedők fokozott halálozásához a T2DM-mel összehasonlítva. Hosszú távon a gyakoribb dialízis mint a hypoglykaemia és a ketoacidosis precipitáló faktora is fenntarthatja ezeket a különbségeket. lrodalom

1. Gagnum V: All-cause mortality in a nationwide cohort of childhood- onset diabetes in Norway 1973-2013. Diabetologia 2015; 58(8): 1779-1786. D0l: $10.1007 / 500125-015-3623-7$

2. Lind $\mathrm{M}$ : Glycemic control and excess mortality in type 1 diabetes. N Engl J Med 2015; 372: 879-881. D01: 10.1056/NEMC1415677

3. Jorgensen ME, Aldmal TP, Carstensen B: Time trends in mortality rates in type 1 diabetes from 2002 to 2011. Diabetologia 2013; 56(11): 2401-2404. D01: 10.1007/ $1500125-013-3025-7$

4. Lung TWC, Hayes AJ, Herman WH, Si L, Palmer AJ, Clarke PM: A meta-analysis of the relative risk of mortality for type 1 diabetes patients compared to the general population: exploring temporal changes in relative mortality. PLOS ONE 2014; 9(11): el13635. D01: 10.1371/journal.pone.0113635

5. Rawshani A, Rawshani A, Franzén S, Eliasson B, Svensson AM, Miftaraj M: Mortality and cardiovascular disease in type 1 and type 2 diabetes. N Engl 3 Med 2017; 376(15): 1407-1418. DOI: 10.1056/NEJMoa1608664

6. Podar T: Mortality in patients with childhoodonset type 1 diabetes in Finland, Estonia, and Lithuania. Diabetes (are 2000; 23(3): 290-294. D01: 10.2337/diacare.23.3.290

7. Hillier TA, Pedula KL: Complications in young adults with early-onset type 2 diabetes: losing the relative protection of youth. Diabetes Care 2003; 26(11): 2999-3005. Dol: 10.2337/diacare.26.11.2999

8. Dart AB: Earlier onset of complications in youth with type 2 diabetes. Diabetes Care 2014; 37(2): 436-443. D01: 10.2337/dc13-0954

9. Al-Saeed AH: An inverse relationship between age of type 2 diabetes onset and complication risk and mortality: the impact of youthonset type 2 diabetes. Diabetes Care 2016; 39(5): 823-829. D01: 10.2337/dc15-0991

10. Eppens MC: Prevalence of diabetes complications in adolescents with type 2 compared with type 1 diabetes. Diabetes Care 2006; 29(6): 1300-1306. DOI: $10.2337 / \mathrm{d} c 05-2470$

11. Wong J: Morbidity and mortality in youngonset type 2 diabetes in comparison to type 1 diabetes: where are now? Curr Diab Rep 2015; 15(1): $566-577.001: 10.1007 / 571892-014-0566-1$
12. López-Cuenca A, Gómez-Molina M, FloresBlanco PJ, Sánchez-Martínez M, García-Narbon A, De Las Heras-Gómezl, et al: Comparison between type-2 and type- 1 myocardial infarction: clinical features, treatment strategies and outcomes. J Geriatr Cardiol 2016; 13(1): 15-22. DOl: 10.11909/ji.issn.1671-5411.2016.01.014

13. Constantino MI: Long-term complications and mortality in young- onset diabetes: type 2 diabetes is more hazardous and lethal than type 1 diabetes. Diabetes Care 2013; 36(12): 3863-3869. 001: $10.2337 / \mathrm{dc} 12-2455$

14. Wibell L, Nystroom L, Ostman J, Arnqvist H, Blohmé $G$, Lithner F, et al: Increased mortality in diabetes during the first 10 years of the disease. A populationbased study (DISS) in Swedish adults 15-34 years old at diagnosis. J Intern Med 2001; 249(3): 263-270. D01: 10.1046/.1.1365-2796.2001.00802.x

15. Dart AB, Sellers EA, Martens PJ, Rigatto C, Brownell $M D$, Dean HJ: High burden of kidney disease in youth-onset type 2 diabetes. Diabetes Care 2012; 35(6): 1265-1271. D01: 10.2337/dc11-2312

16. Luk AO, Lau ES, So WY, Ma RCW, Kong APS, Ozaki $R$, et al: Prospective study on the incidences of cardiovascular-renal complications in Chinese patients with young- onset type 1 and type 2 diabetes. Diabetes Care 2014 37(1): 149-157. D01: $10.2337 / \mathrm{dc} 13-1336$

17. Yokoyama H, Okudaira M, Otani T, Sato A, Miura $\mathrm{J}$, Takaike $\mathrm{H}$, et al:. Higher incidence of diabetic nephropathy in type 2 than in type 1 diabetes in early-onset diabetes in Japan. Kidney Int 2000; 58(1): 302-311. D01: 10.1046/.1523-1755.2000.00166.x

18. Dabelea D, Rewers A, Stafford JM, et al: Trends in the prevalence of ketoacidosis at diabetes diagnosis: the SEARCH for Diabetes in Youth Study. Pediatrics 2014; 133(4): e938-e945. D0I: 10.1542/peds.2013-2795

19. Maahs DM, Hermann JM, Holman N, Foster NC, Kapellen TM, Allgrove J, et al:: Rates of diabetic ketoacidosis: international comparison with 49,859 pediatric patients with type 1 diabetes from England, Wales, the U.S., Austria, and Germany. Diabetes Care 2015; 38(10): 1876-1882. DOI: 10.2337/dC15-0780

20. Barski L, Nevzorov R, Harman-Boehm I, Rabaev E, Zektser M, Zeller L, et al.: Comparison of diabetic ketoacidosis in patients with type-1 and type-2 diabetes mellitus. Am J Med Sci 2013; 345(4): 326-330. D01: 10.1097/MAJ.0b013e31827424ab
21. Giovannucci E, Harlan DM, Archer MC, Bergenstal RM, Gapstur SM, Habel LA, et al:: Diabetes and cancer: a consensus report. Diabetes Care 2010; 33(7): 1674-1685. D01: 10.2337/dc10-0666

22. Sona MF, Myung SK, Park K, Jargalsaikhan G: Type 1 diabetes mellitus and risk of cancer: a metaanalysis of observational studies. Jpn $\mathrm{I}$ Clin Oncol 2018; 48(5): 426-433. D01: 10.1093/ijco/hyy047

23. Gordon-Dseagu VL, Shelton N, Mindell JS: Epidemiological evidence of a relationship between type-1 diabetes mellitus and cancer: a review of the existing literature. Int I Cancer 2013; 132(3): 501-508. D01: 10.1002/ijc.27703

24. Jermendy G, Kempler P, Abonyi-Tóth Z, Rokszin $G$, Wittmann I: Changes in features of diabetes care in Hungary in the period of years 2001-2014. Aims and methods of the database analysis of the National Health Insurance Fund. Orv Hetil 2016; 157(32): 1259-1265.

25. Hothorn T, Bretz F, Westfall P: Simultaneous inference in general parametric models. Biom 1 2008; 50(3):346-363. D01: 10.1002/bimj.200810425

26. Scibilia J, Finegold D, Dorman J, Becker D, Drash A: Why do children with diabetes die? Acta Endocrinol 1986; 279(Suppl): 326-333. DOI: 10.1530/acta.0.112s326

27. Edge JA, Ford-Adams ME, Dunger DB: Causes of death in children with insulin-dependent diabetes, 1990-96. Arch Dis Child 1999; 81(4):318-323. Dol: 10.1136/adc.81.4.318

28. Karges B, Rosenbauer J, Holterhus PM, Beyer P, Seithe H, Vogel C, et al.: Hospital admission for diabetic ketoacidosis or severe hypoglycaemia in 31,330 young patients with type 1 diabetes. Eur $J$ Endocrinol 2015; 173(3): 341-350. DOI: 10.1530/EJE-15-0129

29. Karges B, Schwandt A, Heidtmann B, Kordonouri 0 , Binder $E$, Schierloh $U$, et al: Association of insulin pump therapy vs. insulin injection therapy with severe hypoglycemia, ketoacidosis, and glycemic control among children, adolescents, and young adults with type 1 diabetes. Jama 2017; 318(14): 1358-1366. D01: 10.1001/jama. 2017.13994

30. Rawshani A, Sattar N, Franzén S, Rawshani A, Hattersley AT, Svensson A-M, et al.: Excess mortality and cardiovascular disease in young adults with type 1 diabetes in relation to age at onset: a nationwide, register-based cohort study. Lancet 2018; 392(10146): 477-486. D01: $10.1016 / 50140-6736(18) 31506-X$ 